\title{
The Development of Governance, Leadership, Management System, and the College Quality Guarantee of Accreditation Oriented Study Program
}

\author{
Abdurrahman Adisaputera \\ University State of Medan \\ Medan, Indonesia \\ Abas_750@yahoo.co.id
}

\author{
Sylamsul Arif \\ University State of Medan \\ Medan, Indonesia \\ syamsularifsiregar@gmail.com
}

\begin{abstract}
After studying the accreditation profile of the study program at Universitas Negeri Medan in the first year of this research, in the form of study program performance before and after the accreditation, the accreditation value conformity which was provided by PT BAN with the factual condition of the study program in Unimed, and the frequency of accreditation result utilization for quality improvement, study program performance value before being accredited, this second year research is aimed for designing the development program of accreditation based study program which is contained in Renstra, Renop, RIP Lemlit and LPM. The method used to achieve the purpose of the research is through qualitative approach with evaluation or evaluative study on case studies. It is hoped that the results of this study can be a meaningful feedback for the development of Unimed to become a relevant and reliable college for the future development according to the mission and vision of Unimed. The expected target is preparing the performance review course of study based on the implementation of accreditation standards within the quality development of Unimed. Thus, the result of the long term research is in the form of accreditation-based program design which is found in Renstra, Renop, RIP Lemlit and LPM.
\end{abstract}

Keyword: Quality Development, and Accreditation

\section{INTRODUCTION}

Governance is a kind of system to maintain the effectiveness of the constituents role in the policy development, decision making, and the implementation of study programs. The governance structure includes an active regulatory body with sufficient autonomy to guarantee the integrity of the institution and fulfill the accountability in the development of policies and resources, which is consistent with the vision and mission of the institution. Governance is able to empower a management system which is oriented to the principle of managing higher education in accordance with applicable laws and regulations. With the governance system, it allows the establishment of an administrative system that serves to maintain the effectiveness, efficiency and productivity of the realization of the vision, implementation of the mission, and the objectives achievement and maintaining the integrity of the study program.

The implementation of good governance is reflected in the good functional management system of the study program, which includes planning, organizing, developing staff, directing, supervising, monitoring and evaluating, especially in the educational resources usage, in order to achieve the effectiveness and efficiency of the tertiary education implementation in the scope of the program studies. The developed management system can guarantee the development of academic freedom and scientific autonomy in the study program, as well as encourage the independence in the academic, operational, personnel, financial management and all the needed resources to achieve the expected quality excellence.

To establish good governance, the study program must have strong leadership that can influence all the behaviors of the individuals and group in the goal achievement. A strong leadership is a visionary leadership, which is able to formulate, credible, and interesting for futuristic vision.

In the accreditation documents of the study program in higher education, the reference to the governance quality excellence, the leadership, and the management system of the study programs are used as an integrated entity which is an important key to the success of institutions in realizing the vision, carrying out the mission, and achieving the goals that are dreamed on. The governance is a system that guarantees the organization of the institutions in fulfilling the principles of credibility, transparency, accountability, responsibility and justice. Governance is developed based on the values of moral and ethical, as well as the norms and values of academic.

The description of governance to realize the visions by carrying out the missions and the objectives are not specific/unclear 2. The governance at company level has not been oriented towards management in general and at the Study Program level has not been in operational management 3 . The leadership is weak, especially the public leadership 4. The governance is not supported by SOPs and the guidelines for a complete management system so that the quality of the process is difficult to assess 5 . New quality assurance is carried out informally; it is not yet sustainable; or it is still in the academic field. 6 . The implementation documentation of the quality assurance is incomplete or even nonexistent. 7. Monitoring and evaluation that relate to the implementation of quality assurance is not continuous, and there is no evidence for the document. 8. There is no follow-up of evaluation or feedback 


\section{RESEARCH METHOD}

The method used to achieve the objectives of this study is by using qualitative method, evaluation method or evaluative studies with a qualitative approach through case studies and exploratory. Therefore, the instruments for collecting the data consist of content formats, quality checklists, observation sheets, interview guidelines and documentation.

This research is also a study of higher education quality management policies on the research/effective management field, with the aim of developing the Unimed quality development based on accreditation standards. The evaluation methods or evaluative studies are used to achieve the objectives of this study, with a qualitative approach through case study and explorative study.

In collecting the research data which are in accordance with the needs, four stages of policy research are carried out that referred to the stages prepared by Peter J. Haas and J. Fred Springer (1998: 22), they are: (1) Formulating the problems; (2) Planning the research; (3) Carrying out the research; and (4) Presenting the findings of the study and communicating the recommendations.

\section{RESEARCH RESULTS AND DISCUSSION}

1. Quality Assurance at the Language and Arts Faculty (FBS) of Unimed Based on Accreditation

Today, 9 out of 10 study programs at FBS of Unimed have been accredited by BAN-PT. The achievements of the accreditation of each study program are based on the value of each accreditation standard that can be seen in the figure below.

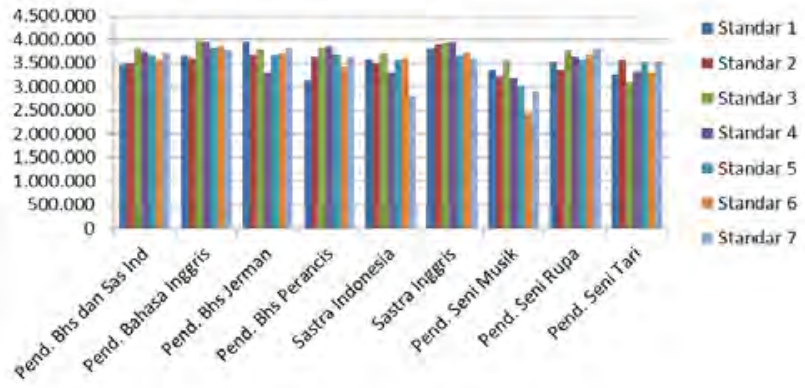

Fig 1 The Result of Study Program Accreditationat the Faculty of Language and Arts of Unimed

Based on the figure as described above, the level of difficulty of the study program at FBS of Unimed in fulfilling the accreditation standards is an obstacle to obtaining the maximum accreditation score which is found in standards one, two, six, and seven. The lowest value obtained in standard one is 3,127 by the French Language Education Study Program, meanwhile the highest score is 3,961 by the German Language Study Program. The other study programs that obtained good scores are Indonesian Language and Literature Education which obtained 3,460, English Education obtained 3,669, Indonesian Literature Study Program obtained 3,585, Music Arts Education Study obtained 3,335, Fine Arts Education Study Program obtained 3,527, and Dance Education Study
Program obtained 3,525. The information traced based on the values obtained in this standard is the difficulty of the study program in aligning the documents prepared in implementing the mechanism for preparing the vision, mission, goals, and objectives of the study program.

2. The Quality Assurance at the Mathematics and Natural Sciences (FMIPA) Faculty of Unimed Based on Accreditation

The Mathematics and Natural Sciences (FMIPA) Faculty of Unimed currently is holding 8 study programs, including 4 education-based study programs and 4 other noneducation based study programs. The results obtained of the accreditation scores for each study program based on the values in each accreditation standard can be seen in the figure below.

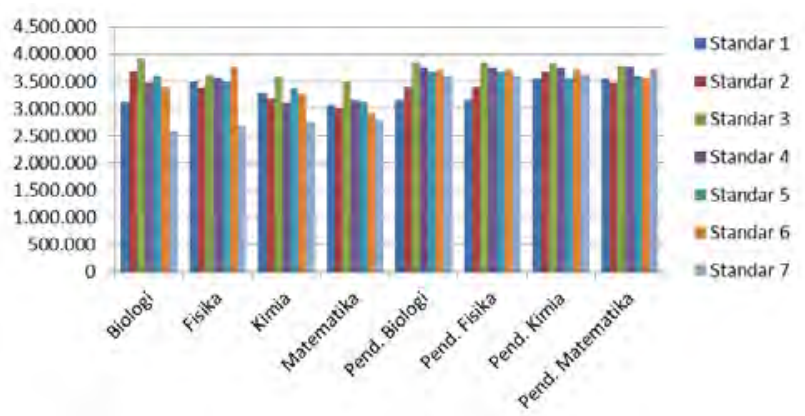

Fig 2. The Result of the Study Program Accreditation at the Mathematics and Natural Sciences (FMIPA) Faculty of Unimed

Based on the data as described in the figure above, the best accreditation score of the study programs at FMIPA Unimed is found in the standard 3 that is the Biology Study Program, which obtained 3,911. Meanwhile, the lowest accreditation score is found in standard 7 which is obtained by Biology Study Program which obtained 2,588, the Physics Study Program obtained 2,702, the Chemistry Study Program obtained 2,752, the Mathematics Study Program obtained 2,781, the Biology Education Study Program obtained 3,604, the Physics Education Study Program obtained 3,604, the Chemistry Education Study Program obtained 3,623, and the Mathematics Education Study Program obtained 3.727. The data shows that the lowest score for standard 7 accreditation forms is obtained by the non-education-based study groups. The score of the publication of research results which is in non-education-based study programs is a major obstacle in increasing the standard form of accreditation score 7 . Besides the standard 7 accreditation forms, the next difficulty level faced by the study programs at FMIPA is the standard 4 and 5 accreditation forms. This is shown by the Chemistry Study Program which obtained 3,103 in standard 3 and the Mathematics Study Program in standard 5 obtained 3,102.

3. The Quality Assurance at the Faculty of Education Science (FIP) of Unimed Based on Accreditation

The existence of the Education Faculty (FIP) of Unimed is very important for the people of North Sumatra. This can be seen from the interest of prospective new students in competing to become students in this faculty. One of the most popular study programs that the community preferred is 
the PGSD Study Program. Based on the results of a research by Sugiyono, et al. (2012), it showed that of the 15 PGSD Study Programs that were the sample of the study, the PGSD Study Program of Unimed ranked first in terms of ratio and the number of tightness of new student selection. The tightness of selection at the PGSD Study Program was Unimed with a ratio of 1: 56.8. In 2016 the number of applicants who enrolled in the PGSD Study Program for the SBMPTN path was 3,969 , meanwhile the capacity was only 128 students.

Besides the PGSD Study Program, The FIP of Unimed also has for Counseling Guidance Study Program, PAUD Teacher Education, and Non-Formal Education. The results of the acquisition of accreditation scores for each study program based on the scores in each accreditation standard can be seen in the figure below.

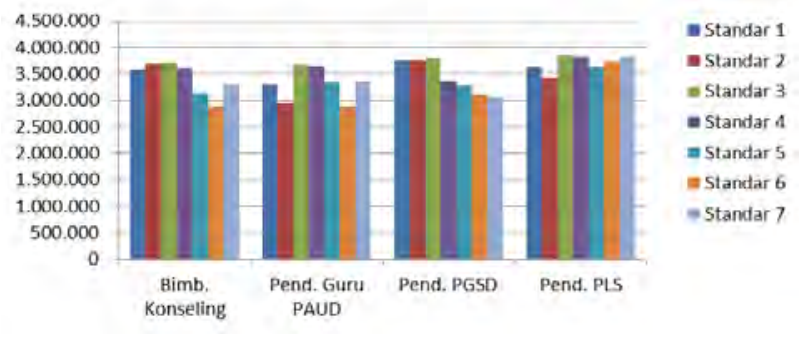

Fig 3. The Accreditation Results of the Study Programat the Education Faculty (FIP) of Unimed

Based on the score data for each accreditation standard form as described in the figure above, the best accreditation score in standard 4 is by the Non-Formal Education Study Program, which obtained 3,817. Meanwhile, the lowest accreditation score is in standard 2. The standard 2 score obtained by the Non-Formal Education Study Program that is 3,424 , the PGSD Study Program obtained 3,752, the PAUD Teacher Education Study Program obtained 2,945, the Counseling Guidance Study obtained 3,702. The difficulty of study programs in FIP of Unimed on the standards of 2 accreditation forms which is based on the results of the analysis on the acquisition of these scores is in the study program efforts to ensure the sustainability of its programs in implementing the quality management, improving the quality of graduates, and achieving the competitive grants.

4. The Quality Assurance at the Social Sciences (FIS) Faculty of Unimed Based on Accreditation

There are four study programs managed by the Social Sciences Faculty (FIS) of Unimed, they are Anthropology Education, Geography Education, Citizenship Education, and Historical Education. The analysis of the difficulty of the study programs in carrying out the accreditation-based quality assurance starts from seeing the results of the acquisition of accreditation scores of each study program which is based on the value of each accreditation standard. This value can be seen in the figure below.

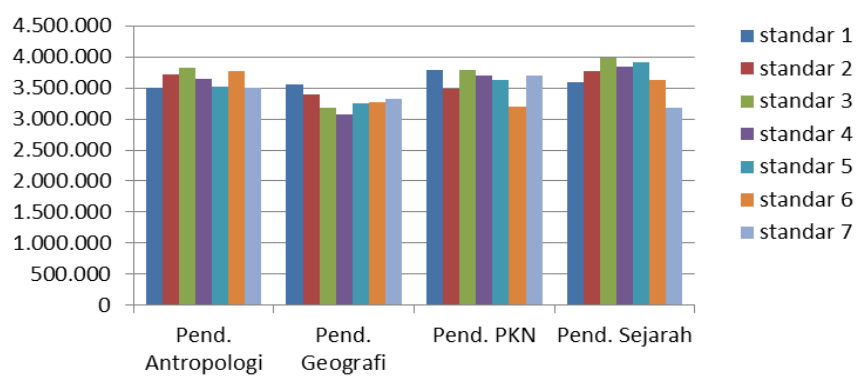

Fig 4. The Accreditation Results of the Study Program at the Social Sciences Faculty (FIS) of Unimed

Based on the data as described in the figure above, it can be seen that the implementation of accreditation-based quality assurance activities has gone well. The acquisition of scores on each standard accreditation form in each study program reaches more than 3.0. The highest value is found in the standard 3 accreditation forms, namely 3,978 obtained by the History Education Study Program. The values that were not much different were also obtained by 3 other study programs, they are the Anthropology Education Study Program which obtained 3,827, the Geography Education Study Program which obtained 3,178, and the Citizenship Education Study Program which obtained 3,785.

5. The Quality Assurance at the Sports Science Faculty (FIK) of Unimed Based on Accreditation

The Sports Science Faculty (FIK) of Unimed currently manages 3 study programs, they are: Sports Science Study Program, Sports and Recreation Physical Education Study Program, and Sports Coaching Education Study Program. The results of the acquisition of accreditation scores for each study program based on the values in each accreditation standard can be seen in the figure below.

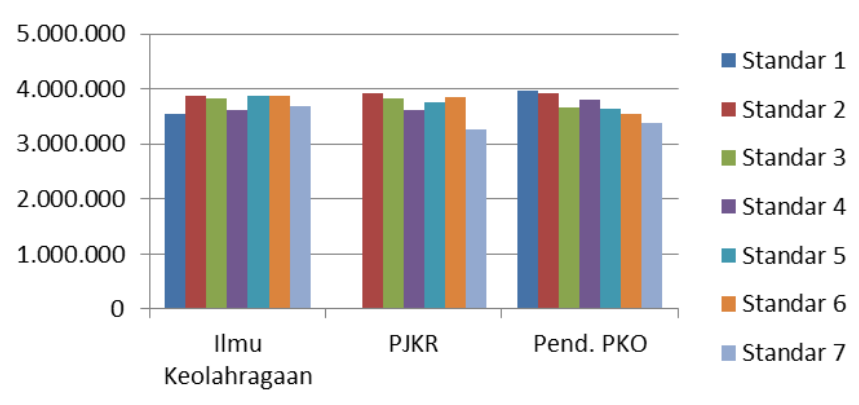

Fig 5 The Accreditation Results of the Study Program at the of Sports Science Faculty (FIK) of Unimed

Based on the data as described in the figure above, the best accreditation score is found in standard 1 for the PJKR Study Program (Sports and Recreation Physical Education), namely 4. Two other study programs also obtained the maximum score for standard 1, which are 3.54 for the Science Study Program Sports and 3,961 for the Sports Coaching Education 
Study Programs. Meanwhile, the lowest accreditation score is found in standard 7. The standard score of 7 is obtained by the PJKR (Sport Physical and Recreational Education) Study Program which obtained 3.26.

6. The Quality Assurance at the Engineering Faculty (FT) of Unimed Based on Accreditation

The Engineering Faculty (FT) of Unimed is currently managing 9 study programs, they are: Cooking School Education Study Program, Fashion Design Education, Cosmetology Education, Building Engineering Education, Electrical Engineering Education, Machine Engineering Education, Automotive Engineering Education, Mechanical Engineering D3, and Engineering D3 Civil. The results of the acquisition of accreditation scores for each study program based on the values in each accreditation standard can be seen in the figure below.

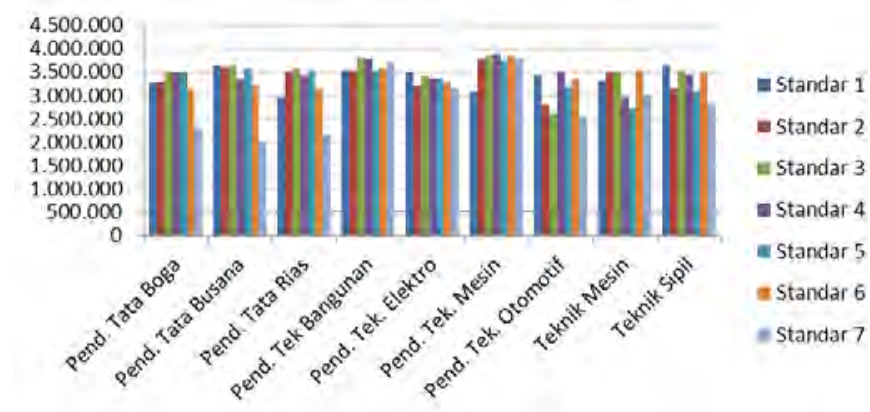

Figure 6 The Accreditation Results of the Study Program Engineering Faculty (FT) of Unimed

Based on the data as described in the figure above, it can be seen that the implementation of accreditation-based quality assurance activities has gone well. The scores achievement on each standard accreditation form in each study program reaches more than 3.0. However, there are some study programs that need to pay attention to the quality of their study program quality management at standard 7. Tata Boga Study Program, Fashion Design Study Program, Makeup Program Study Program still get a score of 2.5 on the standard ,7 so it is necessary to increase the publication of their lecturers' research results in the scientific journals and proceeding national/international scientific meetings.

\section{DISCUSSION}

The implementation of Unimed governance system is based on the Rector's Regulation Number 0242/UN.33/SK/LL/2015 concerning "The Governance Guidelines, Unimed Organizational Structure, Leadership and Management". This regulation constitutes an amendment to the Rector' Regulation Number 0210b/UN. 33/SK/LL/ 2011 in order to adjust the Unimed governance with: (1) Minister of Education and Culture Regulation (Permendikbud) Number 148 of 2014 about the University Organization and Work Procedures (OTK) of Medan City; (2) Law Number 12 of 2012 about Higher Education; (3) Permendikbud Number 50 of 2014 about the Quality Assurance System for Higher
Education; (4) Permendikbud Number 44 of 2015 about the National Standards for Higher Education.

At the implementation level, the ongoing governance structure of Unimed still refers to the Minister of Education Decree No. 207/0/2002 about the Organization and Work Procedure of Medan State University, and is preparing adjustments to the Minister of Education and Culture Regulation No. 148 of 2014 about the Organization and Work Procedures of the new Medan State University.

The Unimed's governance system in the domains of input, process, output, outcome, and impact, as a whole applies credible, transparent, accountable, responsible and fair principles of governance. The support of Unimed's leadership commitment is realized through the implementation of an internal quality assurance system.

Based on the Unimed statute, the instrument that supports the Unimed's governance as a higher education institution is the rector, the senate, the internal supervisory unit, and the quality assurance center. In 2014, Unimed had a new organization and governance that was approved based on Permendikbud No. 148 of 2014, namely by adding Advisory Board and Trustees Board to the existing organizational structure. The Rector as the head of the managing person is the implementing element of Unimed's governance who is assisted by: (1) Vice Rector for academic affairs (WR I), Vice Rector for General and Financial Administration (WR II), Vice Rector for Student Affairs (WRIII) and Vice Rector for the Development and Cooperation (WR IV). (2) Academic executing elements consist of Faculties, Departments and Study Programs (Prodi), Postgraduate Programs (PPs), Research and Community Service Institutions (LPPM), Quality Assurance Institutions (LPM), Educational Development Institutions and Instructional Activities (LP2AI) and other supporting elements. (3) The Elements of administrative implementers include the Academic and Student Administration Bureau (BAAK), the General and Financial Administration Bureau (BAUK), and the Planning and Information Systems Administration Bureau (BAPSI).

Specifically, the supporting instruments for Unimed's governance are: (1) Senate which has functions to review, to give consideration and approval to the rector in the academic field, the setting of norms and academic supervision, (2) the Advisory Council which carries out the function of granting non-academic considerations, (3) The Trustees Board performs the function of assisting the development and funding of Unimed, (4) The Quality Assurance Center (PPM) which is tasked for preparing/designing draft quality policies, accreditation and ethical codes, socializing, facilitating policy implementation, and conducting academic monitoring and evaluation, (5) The Internal Supervisory Unit (SPI) which is tasked with carrying out supervision through non-academic field audits, as well as evaluating the quality of Good University Governance (GUG) implementation

\section{CONCLUSION}

The accreditation scores obtained by a higher education are accumulated scores on all indicators of higher education performance. The score of performance indicators is a numerical score and other forms of information that explains or measures the progress in achieving the mission, goals and 
objectives of a particular educational unit (BAN-PT, Guidelines for Self Evaluation Study Program, 2005). The accreditation status of a higher education reflects the performance of the relevant higher education, and can be a benchmark that describes the quality, efficiency and relevance of a study program that is held. The following is a description of the difficulties of each study program incorporated into the five faculties in Medan State University in implementing the quality assurance system based on the results of the study program accreditation.

\section{REFERENCES}

[1] Berg, Bruce L., 2001. Qualitative Research Methods for the Social Sciences, Fourth Edition, Boston: Allyn and Bacon.

[2] Gaspersz, Vincent, 2001. "Penerapan Total Quality Management in Education (TQME) pada Perguruan Tinggi di Indonesia". dalam :"Jurnal Pendidikan dan Kebudayaan”. No. 029, Tahun Ke-7, Edisi Mei 2001, Balitbang Depdiknas Jakarta.

[3] Rektor Unimed, 2010. Renstra Universitas Negeri Medan 2016-2020. Medan: Unimed Press.

[4] Unimed, 2011. Rencana Induk Penenlitian (RIP) Universitas Negeri Medan 2012-2016. Medan: Unimed Press.

[5] BAN-PT, Pedoman Evaluasi-diri Program Studi, 2005.

[6] Depdiknas, Undang-undang no 20 Tahun 2003 Tentang Sistem Pendidikan Nasional.

[7] Depdiknas; Peraturan Pemerintah no 19 tahun 2005 Tentang Standar Nasional Pendidikan. 